\title{
Differences in the Stability of the Plasmids of Yersinia pestis Cultures in Vitro: Impact on Virulence
}

\author{
TC Leal-Balbino+ ${ }^{+}$NC Leal, CV Lopes, AM P de Almeida
}

\author{
Departamento de Microbiologia, Centro de Pesquisas Aggeu Magalhães-Fiocruz, Campus da UFPE, Cidade Universitária, \\ 50670-420 Recife, PE, Brasil
}

\begin{abstract}
Plasmid and chromosomal genes encode determinants of virulence for Yersinia pestis, the causative agent of plague. However, in vitro, Y. pestis genome is very plastic and several changes have been described. To evaluate the alterations in the plasmid content of the cultures in vitro and the impact of the alterations to their pathogenicity, three Y. pestis isolates were submitted to serial subculture, analysis of the plasmid content, and testing for the presence of characteristic genes in each plasmid of colonies selected after subculture. Different results were obtained with each strain. The plasmid content of one of them was shown to be stable; no apparent alteration was produced through 32 subcultures. In the other two strains, several alterations were observed. $L D_{50}$ in mice of the parental strains and the derived cultures with different plasmid content were compared. No changes in the virulence plasmid content could be specifically correlated with changes in the $L D_{50}$.
\end{abstract}

Key words: plague - Yersinia pestis plasmids - virulence

Plasmid and chromosomal genes encode determinants of virulence for Yersinia pestis, the causative agent of plague (Perry \& Fetherston 1997, Parkhill et al. 2001, Deng et al. 2002). A 102-kb, unstable chromosomal area (locus pgm) is essential for Y. pestis virulence (Fetherston et al. 1992, Hinnebusch et al. 1996, Buchrieser et al. 1998).

Typical strains of $Y$. pestis harbour three plasmids: pPst $(9.5 \mathrm{~kb})$, encoding a plasminogen activator protease (Pla) (Sodeinde \& Goguen, 1988, 1989); pFra (90kb), encoding a capsular protein Fraction 1 (F1) with antiphagocytic activities (Du et al. 2002) and murine toxin (Ymt), required for survival in the flea (Hinnebusch et al. 2002); pYV (70kb), encoding the Yop virulon which comprises both the Yop effectors proteins and the proteins necessary for injecting them into host cells. The Yop virulon enables the bacteria to survive and multiply in the lymphoid tissues of the host (Cornelis 2002). Several insertion sequences (IS100, IS200, IS285) present in the three plasmids favour recombination events and genetic plasticity (Filippov et al. 1995, Parkhill et al. 2001, Deng et al. 2002).

However, atypical strains lacking some plasmids have been found in several foci around the world. On the other hand, strains containing extra DNA bands or additional cryptic plasmids have also been found (Filippov et al. 1990, Chu et al. 1998). In vitro, Y. pestis genome is very plastic and several changes have been described: emergence of additional DNA-bands, increasing of plasmid molecular mass, and integration of plasmids into the bacterial chromosome with or without loss of functions (Zsigray et al. 1985, Protsenko et al. 1991). Furthermore, the typical plasmids may be eliminated spontaneously at

Financial support: CNPq, Fiocruz (Papes 3), Facepe

${ }^{+}$Corresponding author. Fax: +55-81-3453 2449. E-mail: cristina@cpqam.fiocruz.br

Received 2 March 2004

Accepted 6 October 2004 a high frequency during storage in the laboratory or through successive subcultures (Protsenko et al. 1991).

The study of the plasmid content of $Y$. pestis isolates from the plague foci of Northeast Brazil, stored in the laboratory for several decades, showed that some of them displayed an atypical plasmid profile characterized by the absence of some plasmids or by the presence of extra DNA bands (Leal et al. 1997a, Leal \& Almeida 1999, Cavalcanti et al. 2002). The absence of plasmids and the emergence of extra-DNA bands in the Brazilian isolates could also have been produced during storage or handling in the laboratory.

To observe possible alterations in plasmids of the cultures in vitro and the impact of the alterations to their pathogenicity, three low subcultured and highly pathogenic $Y$. pestis isolates were submitted to serial subcultures. Colonies selected after subcultures were analyzed for their plasmid content and the presence of some characteristic genes of each plasmid. $\mathrm{LD}_{50}$ in mice of the parental strains and derived cultures displaying different plasmid contents were compared.

\section{MATERIALS AND METHODS}

Bacteria and culture conditions - The study involved two Brazilian isolates: one old (P. Exu 340, originating from a finger bone marrow in a fatal human case in 1969), and the most recent Brazilian isolate (P. CE 882, originating from a hemoculture from a plague case in 1997), and one isolate from another South America focus for comparison (P. Peru 375 originating from a plague patient from Peru in 1994). For this work a loopful of each parental culture was grown in BHI (brain heart infusion broth, Difco Laboratories, Detroit, MI, US) at $28^{\circ} \mathrm{C}$ for $24 \mathrm{~h}$ followed by streaking on $\mathrm{BAB}$ (blood agar base, Difco) for $48 \mathrm{~h}$. Isolated colonies were picked and grown in $\mathrm{BHI}$ and the plasmid content of each culture was determined. The derivative cultures were named YP (for Y. pestis), the number of the parental culture followed by the number of the subculture (Table). 
TABLE

Plasmid content of the cultures studied, amplification of plasmid, and chromosomal genes by polymerase chain reaction (PCR) and virulence for mice

\begin{tabular}{|c|c|c|c|c|c|c|c|c|c|c|c|}
\hline \multirow[b]{2}{*}{ Identification } & \multirow{2}{*}{$\begin{array}{l}\mathrm{Nr} \text { of the } \\
\text { subculture }\end{array}$} & \multirow{2}{*}{$\begin{array}{l}\text { Pigmentation } \\
\text { in Congo } \\
\text { red agar plates }\end{array}$} & \multicolumn{3}{|c|}{ Presence of plasmids } & \multicolumn{5}{|c|}{ Amplification by PCR } & \multirow{2}{*}{$\begin{array}{l}\mathrm{LD}_{50} \\
(\mathrm{CFU})\end{array}$} \\
\hline & & & pFra & pYV & pPst & cafl & $y m t$ & $l c r V$ & pla & irp2 & \\
\hline P. CE 882 & Stock & + & + & + & + & + & + & + & + & + & $>4 \times 10^{3}$ \\
\hline YP 882/4 & 4 & + & + & + & + & + & + & + & + & + & $\mathrm{Nd}$ \\
\hline YP $882 / 18$ & 18 & + & + & + & + & + & + & + & + & + & $\mathrm{Nd}$ \\
\hline YP $882 / 22$ & 22 & + & + & + & + & + & + & + & + & + & $\mathrm{Nd}$ \\
\hline YP $882 / 32$ & 32 & + & + & + & + & + & + & + & + & + & $>4 \times 10^{3}$ \\
\hline P. Exu 340 & Stock & + & - & + & + & - & + & + & + & + & $6 \times 10^{0}$ \\
\hline YP $340 / 10$ & 10 & - & - & + & + & - & - & + & + & - & $\mathrm{Nd}$ \\
\hline YP 340/12 & 12 & - & - & + & + & - & - & + & + & - & $\mathrm{Nd}$ \\
\hline YP $340 / 15$ & 15 & - & - & + & + & - & - & + & + & - & $>6 \times 10^{8}$ \\
\hline P. Peru 375 & Stock & + & - & + & + & + & + & + & + & + & $8 \times 10^{0}$ \\
\hline YP 375/4a & 4 & + & - & + & + & + & + & + & + & + & $1 \times 10^{1}$ \\
\hline YP 375/4b & 4 & + & - & + & + & + & - & + & + & + & $\mathrm{Nd}$ \\
\hline YP 375/4c & 4 & - & - & + & + & + & - & + & + & + & $>1 \times 10^{4}$ \\
\hline YP 375/4d & 4 & + & - & + & - & + & - & + & - & + & $3 \times 10^{1}$ \\
\hline YP 375/10 & 10 & + & - & + & - & + & - & + & - & + & $\mathrm{Nd}$ \\
\hline YP 375/16 & 16 & - & - & + & + & - & - & + & + & - & $\mathrm{Nd}$ \\
\hline YP 375/22 & 22 & - & - & + & + & - & - & + & + & - & $8 \times 10^{5}$ \\
\hline
\end{tabular}

$\mathrm{Nd}$ : not done; CFU: colony forming units

Subcultures on Congo red agar plates (CRA) - Each derivative culture was submitted to serial CRA. This medium is used as a phenotypic marker for chromosomal pathogenicity enabling us to differentiate red-pigmented virulent $(\mathrm{Pgm}+)$ colonies and white avirulent (Pgm-) colonies (Jackson \& Burrows 1956, Surgalla et al. 1970, Fetherston et al. 1992). Colonies selected from the CRA plates were grown in BHI and immediately analyzed for their plasmid content, the presence of specific plasmid genes and virulence in mice.

DNA procedures - Plasmid DNA was extracted by the alkaline lysis method of Birnboim and Doly (1979) and electrophoresed in $0.6 \%$ agarose gels in Tris-borate buffer at a constant voltage of $100 \mathrm{~V}$, followed by staining with ethidium bromide $(10 \mathrm{mg} / \mathrm{ml})$ and visualisation under UV. The plasmid sizes were determined by comparison with plasmids of known sizes $(147,63,35.8,6.9 \mathrm{~kb})$ present in Escherichia coli 39R861 and the prototypical plasmids of the vaccine strain Y. pestis EV76 ( 100, 70, $9.5 \mathrm{~kb})$. Total DNA was extracted according to Maniatis et al. (1989) and quantified after electrophoresis in $1 \%$ agarose gels by comparison with a known amount of $\lambda$ HindIII DNA.

PCR analysis - Amplification of the plasmidial genes caf1 (506 pb) located on pFra, pla $(920 \mathrm{pb})$ located on pPst, lcrV (800 pb) located on pYV and the chromosomal gene irp2 (300 pb) was performed as described by Leal and Almeida (1999) using primers designed from published sequences (Sodeinde \& Goguen 1989, Galyov et al. 1990, Motin et al. 1992, Guilvout et al. 1993). The gene irp2 was included in this study as a chromosomal pathogenicity marker (Buchrieser et al. 1998). Amplification of the gene $y m t$ located on pFra was performed according to Leal et al. (1997b) with primers drawn by the program PrimerSelect (DNAstar, Inc.).

Western-blot - Total proteins were extracted from cells collected by centrifugation from $1 \mathrm{ml}$ of the broth culture that was incubated at $28^{\circ} \mathrm{C}$ overnight. The pellet was suspended in $100 \mu \mathrm{l}$ of Laemmli buffer, boiled for $10 \mathrm{~min}$, and electrophoresed in homogeneous, $12.5 \%$ sodium dodecyl sulphate-polyacrylamide gels (SDS-PAGE) followed by staining with Coomassie-blue $\mathrm{R}$ or transferred to polyvinylidene fluoride (PDVF) membranes (ImmobilonMillipore, MA, US). Molecular weight markers were (LMW): phosphorylase b (94 kDa) albumin (67 kDa), ovalbumin $(43 \mathrm{kDa})$, carbonic anhydrase $(30 \mathrm{kDa})$, trypsin inhibitor (20.1 kDa), and lactalbumin (14.4 kDa) (Amersham Biosciences of Brazil Ltd, SP, Brazil). For immunoblot, protein bands were transferred to PDVF membranes at $600 \mathrm{~V}$. Membrane proteins were successively incubated with rabbit anti-F1 antigen polyclonal serum and peroxidase-conjugated goat anti-rabbit globulins (Amersham). Bound antibodies were detected by diaminobenzidine (DAB) (Sigma, MO, US). Rabbit anti-F1 antigen polyclonal serum was prepared following protocols described by $\mathrm{Chu}$ (2000).

Virulence in mice - Animal experiments were carried out with the approval of the local ethics committee (Ceua/ Fiocruz P0049-00). Tenfold serial dilution $\left(10^{-1}\right.$ to $\left.10^{-9}\right)$ in sterile normal saline was prepared from BAB slants of each culture grown at $28^{\circ} \mathrm{C}$ for $48 \mathrm{~h}$. Four dilutions of each culture were tested in Swiss-Webster mice, five to six weeks of age, obtained from the facilities of the Centro de Pesquisas Aggeu Magalhães (CPqAM), Recife, Brazil. Four mice were inoculated with each dilution; each animal received $0.2 \mathrm{ml}$ of suspension containing from $6 \times 10^{0}$ to 6 
$\mathrm{x} 10^{8}$ bacteria by the subcutaneous route. The animals were observed for two weeks. The number of bacteria per dose was determined by plate count of CFUs (colony forming units) on $\mathrm{BAB}$ plates. $\mathrm{LD}_{50}$ were calculated by the Reed and Muench method (1938).

\section{RESULTS AND DISCUSSION}

Analysis of the strain P. CE 882 - The determination of the plasmid content, after electrophoresis on agarose gels, of P. CE 882 and its derived cultures analyzed respectively after the 4th, 18th, 22nd, and 32nd subcultures, revealed the presence of the three typical plasmids: pFra, pYV and pPst in all of them. Neither curing of plasmids nor emergence of extra DNA bands was observed through 32 subcultures of that strain (Table, Fig. 1a, d).

As expected, all DNA segments of sizes corresponding to the genes: cafl (506 bp) and ymt (850 bp) located in pFra, $l c r V(800 \mathrm{bp})$ in pYV, and pla $(920 \mathrm{bp})$ in pPst were amplified in the parental strain P. CE 882 and its derived cultures. The gene irp2 (300 bp) used as a chromosomal pathogenicity marker was also amplified (Table, Fig. 2a).

As shown in the Table there was no difference between the $\mathrm{LD}_{50}$ of P. CE 882 and the culture YP 882/32 obtained after 32 subcultures $\left(\mathrm{LD}_{50}:>4 \times 10^{3}\right)$. However, it is worth pointing out that these $\mathrm{LD}_{50}$ values are higher than the one obtained at isolation $\left(\mathrm{LD}_{50}:<10\right.$ ) (Aragão et al. 2002). In spite of its apparent stability (no alteration had been detected though 32 subcultures) and for reasons still not explained, its virulence in mice was decreased.

Analysis of the strain P. Exu 340 - After electrophoresis on agarose gels, only the plasmids pYV and pPst were visualised in the culture recovered from the bacterial collection (Table, Fig. 1b); also, the genes lcrV and pla located respectively in these two plasmids were amplified by PCR. The plasmid pFra was not visualised and the gene cafl was not amplified. However, in spite of the absence of pFra and lack of amplification of cafl, the gene $y m t$ was amplified in this culture and in its derived cultures until the 9th subculture. From the 10th subculture onward, there was no further amplification of this gene (Table, Fig. 2b).

Three types of alterations of pFra have been described: integration into the chromosome with or without loss of function, mutation in the operon $f 1$, and curing of this plasmid without integration into the chromosome (Protsenko et al. 1991). The integration of pFra into the chromosome seems to be quite frequent, occurring at multiple sites, and can be due to the presence of insertion elements (Filippov et al. 1995, Parkhill et al. 2001).

The loss of pFra in P. Exu 340 might have occurred in the laboratory, because the presence of the gene $y m t$ was still detected by PCR from the culture recovered from the collection and from its derived cultures until the 9th subculture, disappearing only after the 10th subculture. Pos-

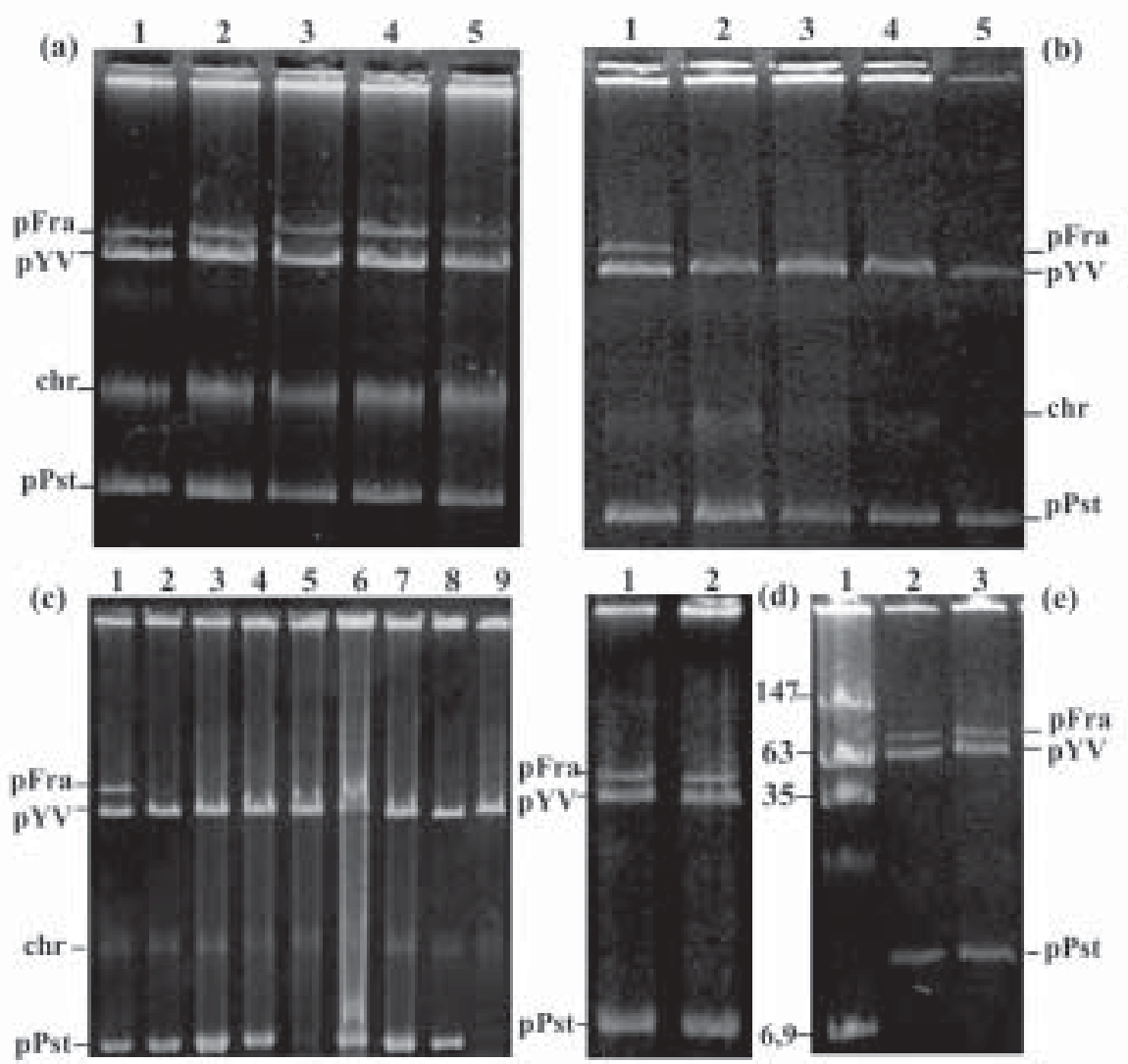

Fig. 1: plasmid content of Yersinia pestis cultures in 0.6\% agarose gel. (a) lines - 1: P. CE 882, 2: YP 882/4, 3: YP 882/18, 4: YP 882/22, 5: YP 882/32; (b) lines - 1: P. CE 882, 2: P. Exu 340, 3: YP 340/10, 4: YP 340/12, 5: YP 340/15; (c) lines - 1: P. CE 882, 2: YP 375/4a, 3: YP 375/4c, 4: YP 375/4b, 5: YP 375/4d, 6: P. Peru 375, 7: YP 375/16, 8: YP 375/22, 9: YP 375/10; (d) lines - 1: Y. pestis EV76, 2: P.CE 882; (e) lines - 1: E. coli R861, 2: Y. pestis EV76, 3: P. Peru 375 (wild) 
(a)

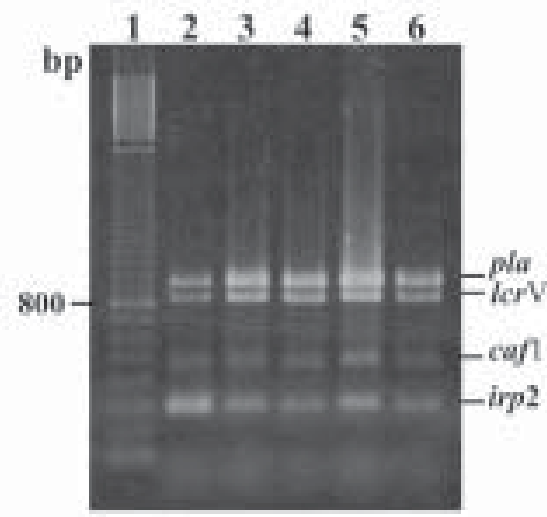

(b)

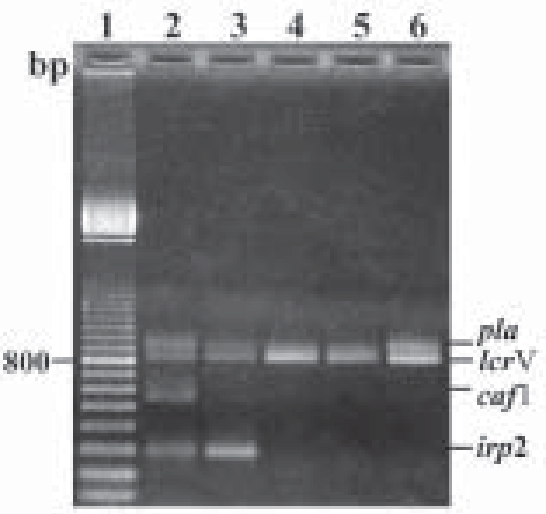

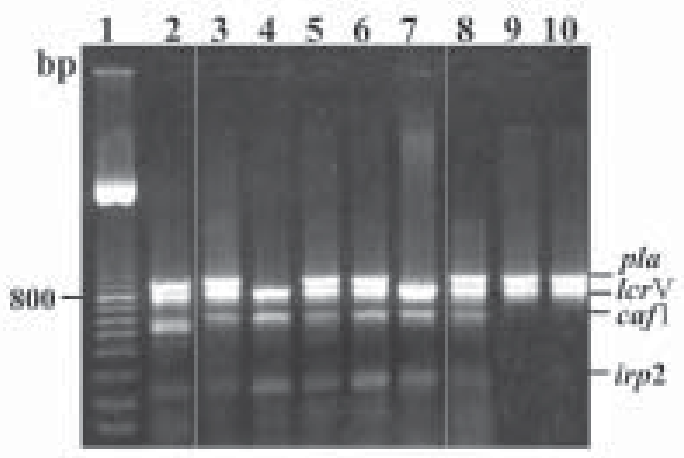

(c)

Fig. 2: amplification of the genes pla (920 bp), lcrV (800 bp), caf1 (506 bp) and irp2 (300 bp), in the cultures examined. (a) lines - 1: 100pb DNA ladder, 2: P. CE 882, 3: YP 882/4, 4: YP 882/18, 5: YP 882/22, 6: YP 882/32; (b) lines - 1: 100-pb DNA ladder, 2: P. CE 882, 3: P. Exu 340, 4: YP 340/10, 5: YP 340/12, 6: YP 340/15; (c) lines - 1: 100-pb DNA ladder, 2: P. CE 882, 3: YP 375/4b, 4: YP 375/10, 5: YP 375/4a, 6: YP 375/4c, 7: YP 375/4d, 8: P. Peru 375, 9: YP 375/16, 10: YP 375/22

sibly, there was a transiently integration of ymt into the chromosome and its elimination afterwards. An equally likely possibility is that a significant portion, but not all, of the bacteria in the colony have lost the plasmid.

Despite the absence of pFra and cafl, P. Exu 340 was shown to be highly virulent in mice $\left(\mathrm{LD}_{50}: 6 \times 10^{0}\right)$ (Table).

Chromosomal alteration in this culture, revealed by the growth of non-pigmented colonies on CRA plates and the loss of the gene irp2 (Pgm-irp2-) also occurred (Table). Brubaker (1969), related that spontaneous non-pigmented mutants arise at a frequency of $\sim 10^{5}$. However, this frequency may vary among the strains (Iteman et al. 1993, Cavalcanti et al. 2002).

Non-pigmented (Pgm-) cultures are avirulent in mice by subcutaneous route of infection (Jackson \& Burrows 1956, Une \& Brubaker 1984) and Pgm- irp2- cultures are avirulent by both subcutaneous and intravenous routes (Almeida et al. 1993, Iteman et al. 1993). As expected, the culture YP 340/15 (Pgm- irp2-), lacking pFra, caf1 and ymt was shown to be avirulent $\left(\mathrm{LD}_{50}:>6 \times 10^{8}\right)$.

Analysis of the strain P. Peru 375 - P. Peru 375 harboured the three plasmids at isolation (Fig. 1e, line 3); however, in this work only pPst and pYV were visualized after electrophoresis, in the culture recovered from the stock. This suggests spontaneous curing of $\mathrm{pFra}$ during storage (Table, Fig. 1c, d). The genes cafl and ymt were still amplified by PCR (Table, Fig. 2c); they were probably integrated into the chromosome.

Plasmid and chromosomal alterations were not produced at the same time in the whole population of P. Peru 375. Four phenotypes were observed on CRA plates after its 4 th subculture. One colony of each phenotype was analyzed and differences in their plasmid content was also found (Table, Fig. 2c).

The culture YP 375/4a displayed the same characteristics as those of the parental strain and their $\mathrm{LD}_{50}$ were quite similar ( $8 \times 10^{0}$ and $1 \times 10^{1}$, respectively). In YP 375/4b, $y m t$ was not amplified. In YP 375/4c, ymt was also absent and, additionally, this colony was Pgm- on CRA plates (chromosomal pathogenicity marker) and had a higher $\mathrm{LD}_{50}\left(>1 \times 10^{4}\right)$. In YP 375/4d and YP 375/10, cafl was amplified, but not ymt; additionally, pPst was not visualized and the gene pla was not amplified. The $\mathrm{LD}_{50}$ of YP $375 / 4 d$ lacking pFra and pPst was very low $\left(3 \times 10^{1}\right)$.

The gene cafl was amplified from the cultures lacking pFra obtained up to the 16th subculture of P. Peru 375; however, afterwards, it was no longer amplified at the same time that only Pgm- irp2- colonies were found on CRA plates (Table). As expected, the culture YP 375/22 (Pgmirp2-) lacking pFra, cafl and ymt was shown to be avirulent $\left(\mathrm{LD}_{50}: 8 \times 10^{5}\right)$.

The presence of the gene caf 1 was determined by PCR in cultures lacking pFra indicating that it could be integrated into the chromosome. To investigate if the $f 1$ op- 
eron was functional, the protein content of P. Peru 375 and four derived cultures (pFra-cafl+) was analyzed. A protein band of approximately $17 \mathrm{kDa}$, corresponding to the F1 antigen encoded by the gene cafl, was visualized in all the cultures examined. Furthermore, anti-F1 specific antibodies recognized these protein bands by immunoblot (Fig. 3). Therefore, the loss of virulence in some cultures derived from P. Peru 375 was due rather to concomitant alterations at the locus pgm (to be published elsewhere) (Fetherston et al. 1992, Buchrieser et al. 1998) than to the curing of pFra or pPst plasmids (Table). Non-pigmented (Pgm-) cultures are avirulent in mice by subcutaneous route of infection (Jackson \& Burrows 1956, Une \& Brubaker 1984). Accordingly, Kutyrev et al. (1989), Drozdov et al. (1995), and Almeida et al. (2003) have already shown that the virulence of $Y$. pestis in laboratory or wild animals is not hampered by the loss of pPst or pFra. In addition, the occurrence of wild $Y$. pestis variants missing pFra in some plague foci and their participation in the epizootic processes was noted (Kutyrev et al. 1989). Furthermore, Y. pestis strains unable to produce some virulence factors were isolated from plague patients or from rodents and fleas and they were supposed to cause mild or even fatal plague (Williams et al. 1978).

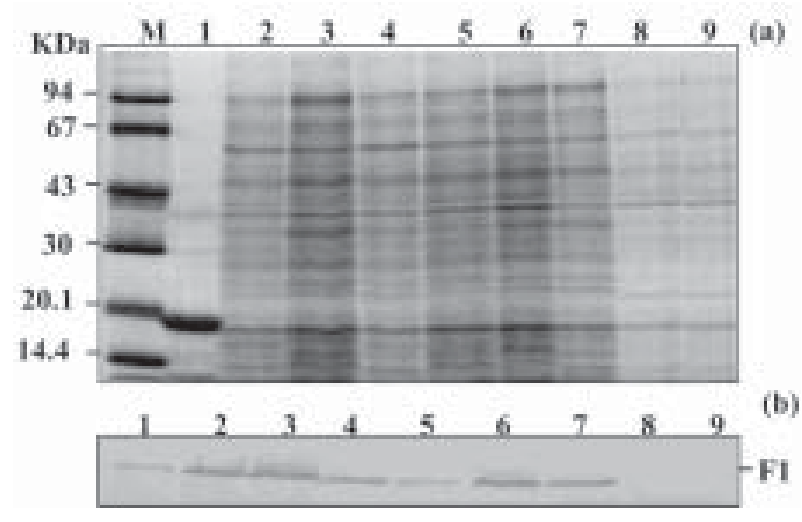

Fig. 3: sodium dodecil sulphate polyacrilamide gel, $12.5 \%$, of the total proteins of P. Peru 375 and derived cultures. (a) lines - 1: F117KDa, 2: P. Peru 375, 3: YP 375/4d, 4: YP 375/4a, 5: YP 375/4c, 6: YP 375/4b, 7: YP 375/10, 8: YP 375/16, 9: YP 375/22. M: molecular weight markers (LMW): phosphorylase b $(94 \mathrm{kDa})$ albumin $(67 \mathrm{kDa})$, ovalbumin $(43 \mathrm{kDa})$, carbonic anhydrase $(30 \mathrm{kDa})$, trypsin inhibitor $(20.1 \mathrm{kDa})$, lactalbumin $(14.4 \mathrm{kDa})$ and westernblot analysis with anti-F1 antibody (b)

In conclusion, the stability of $Y$. pestis plasmids varied among the strains studied. As observed previously (Leal et al. 1997a), pYV was found to be the most stable and pFra the most unstable, followed by pPst. Plasmids of P. CE 882 were shown to be quite stable; no apparent alteration occurred through 32 subcultures. However, for reasons still unknown, its virulence in mice decreased. In the other two strains, serial passage resulted in loss of the three plasmids normally found in Y. pestis. No changes in the virulence plasmid content could be specifically correlated with changes in the $\mathrm{LD}_{50}$. Studies are in progress for better understanding the genetic mechanism of the stability of the plasmids of $Y$. pestis.

\section{ACKNOWLEDGEMENTS}

To Silvana Santos and Yara Nakazawa (CPqAM-Fiocruz) for their technical assistance.

\section{REFERENCES}

Almeida AMP, Alves LC, Amaral RLG, França WGB, Leal NC 2003. Transmission of Yersinia pestis cultures with different plasmid content from Xenopsylla cheopis to Calomys callosus. Parasitol Res 89: 159-162.

Almeida AMP, Guiyoule A, Guilvout I, Iteman I, Baranton G, Carniel E 1993. Chromosomal irp2 gene in Yersinia: distribution, expression, deletion and impact on virulence. $\mathrm{Mi}$ crobial Pathogen 14: 9-21.

Aragão AI, Seoane ACM, Leal TCA, Leal NC, Almeida AMP 2002. Vigilância da peste no Estado do Ceará: 1990-1999. Rev Soc Bras Med Trop 35: 143-148.

Birnboim HC, Doly J 1979. A rapid alkaline extraction procedure for screening recombinant plasmid DNA. Nucleic Acids Res 7: 1513-1523.

Brubaker RR 1969. Mutation rate to nonpigmentation in Pasteurella pestis. J Bacteriol 98: 1404-1406.

Buchrieser C, Prentice M, Carniel E 1998. The 102-kilobase unstable region of Yersinia pestis comprises a high-pathogenicity island linked to a pigmentation segment which undergoes internal rearrangement. J Bacteriol 180: 2321-2329.

Cavalcanti YVN, Leal NC, Almeida AMP 2002. Typing of Yersinia pestis isolates from the state of Ceará, Brazil. Lett Appl Microbiol 35: 543-547.

Chu M 2000. Laboratory Manual of Plague Diagnostic Tests, CDC/WHO, Geneve, 129 pp.

Chu MC, Dong XQ, Zhou X, Garon C 1998. A cryptic 19kilobase plasmid associated with U.S. isolates of Yersinia pestis: a dimer of the 9,5-kilobase plasmid. Am J Trop Med Hyg 59: 679-686.

Cornelis GR 2002. Yersinia type III secretion: send in the effectors. J Cell Biol 158: 401-408.

Deng W, Burland V, Plunkett 3rd G, Boutin A, Mayhew GF, Liss P, Perna NT, Rose DJ, Mau B, Zhou S, Schwartz DC, Fetherston JD, Lindler LE, Brubaker RR, Plano GV, Straley SC, McDonough KA, Nilles ML, Matson JS, Blattner FR, Perry RD 2002. Genome sequence of Yersinia pestis KIM. J Bacteriol 184: 4601-4611.

Drozdov IG, Anisimov AP, Samoilova SV, Yezhov IN, Yeremin SA, Karlyshev AV, Krasilnikova VM, Kravchenko VI 1995. Virulent non-capsulate Yersinia pestis variants constructed by insertion mutagenesis. J Med Microbiol 42: 264-268.

Du Y, Rosqvist R, Forsberg A 2002. Role of fraction 1 antigen of Yersinia pestis in inhibition of phagocytosis. Infect Immun 70: 1453-1460.

Fetherston JD, Schuetze P, Perry RD 1992. Loss of the pigmentation phenotype in Yersinia pestis is due to the spontaneous deletion of $102 \mathrm{~kb}$ of chromosomal DNA which is flanked by a repetitive element. Mol Microbiol 6: 26932704.

Filippov AA, Solodovnikov NS, Kookleva LM, Protsenko AO 1990. Plasmid content in Yersinia pestis strains of different origin. FEMS Microbiol Lett 55: 45-48.

Filippov AA, Oleinikov PN, Motin VL, Protsenko OA, Smirnov GB 1995. Sequencing of two Yersinia pestis IS elements, IS285 and IS 100. Contrib Microbiol Immunol 13: 306-309.

Galyov EE, Smirnov OYu, Karlishev AV, Volkovoy KI, Denesyuk AI, Nazimov IV, Rubtsov KS, Abramov VM, Dalvadyanz SM, Zav'yalov VP 1990. Nucleotide sequence of the Yersinia pestis gene encoding F1 antigen and the primary structure of the protein. FEBS Lett 277: 230-232.

Guilvout I, Mercereau-Puijalon O, Bonnefoy S, Pusgsley A, 
Carniel E 1993. High-molecular-weight protein 2 of Yersinia enterocolitica is homologous to AngR of Vibrio anguillarum and belongs to a family of proteins involved in nonribosomal peptide synthesis. J Bacteriol 175: 5488-5504.

Hinnebusch BJ, Perry RD, Schwan TG 1996. Role of Yersinia pestis hemin storage $(\mathrm{hms})$ locus in the transmission of plague by fleas. Science 273: 367-370.

Hinnebush BJ, Rudolph AE, Cherepanov P, Dixon JE, Schwan TG, Forsberg A 2002. Role of Yersinia murine toxin in survival of Yersinia pestis in the midgut of the flea vector. Science 296: 733-735.

Iteman I, Guiyoule A, Almeida AMP, Guilvout I, Baranton G, Carniel E 1993. Relationship between loss of pigmentation and deletion of the chromosomal iron-regulated irp2 gene in Yersinia pestis evidence for separate but related events. Infect Immun 61: 2717-2722.

Jackson S, Burrows TW 1956. The virulence enhancing effect of iron on non-pigmented mutants of virulent strains of Pasteurella pestis. Br J Exp Pathol 37: 577-583.

Kutyrev VV, Filippov AA, Oparina OS, Protsenko AO 1989. Genetic analysis and modeling of the virulence of Yersinia pestis. Mol Genet Mikrobiol Virusol 8: 42-47.

Leal NC, Almeida AMP 1999. Diagnosis of plague and identification of virulence markers in Yersinia pestis by multiplexPCR. Rev Inst Med Trop São Paulo 41: 339-342.

Leal NC, Farias RCL, Silva MSB, Leal TCA, Almeida AMP, Ferreira LCS 1997a. Plasmid profiles of Yersinia pestis strains isolated in Northeast Brazil. Rev Microbiol 28: 4045.

Leal TCA, Leal NC, Almeida AMP 1997b. Marcadores de patogenicidade em Yersinia enterocolitica O:3 isoladas de suínos do Rio de Janeiro. Pesq Vet Bras 17: 19-24.

Maniatis T, Frisch E, Sambrook J 1989. Molecular Cloning: a Laboratory Manual, Cold Spring Harbor Laboratory, NY.

Motin VL, Pokrovskaya MS, Telepnev MV, Kutyrev VV, Vidyaeva NA, Filippov AA, Smirnov GB 1992. The difference in the $l c r V$ sequences between $Y$. pestis and $Y$. pseudotuberculosis and its application for characterization of $Y$. pseudotuberculosis strains. Microb Pathog 12: 165-175.

Parkhill J, Wren BW, Thomson NR, Titball RW, Holden MT, Prentice MB, Sebaihia M, James KD, Churcher C, Mungall KL, Baker S, Basham D, Bentley SD, Brooks K, CerdenoTarraga AM, Chillingworth T, Cronin A, Davies RM, Davis P, Dougan G, Feltwell T, Hamlin N, Holroyd S, Jagels K, Karlyshev AV, Leather S, Moule S, Oyston PC, Quail M, Rutherford K, Simmonds M, Skelton J, Stevens K, Whitehead S, Barrell BG 2001. Genome sequence of Yersinia pestis, the causative agent of plague. Nature 413: 523-527.

Perry RD, Fetherston JD 1997. Yersinia pestis-etiologic agent of plague. Clin Microb Rev 10: 35-66.

Protsenko OA, Filippov AA, Kutyrev VV 1991. Integration of the plasmid encoding the synthesis of capsular antigen and murine toxin into Yersinia pestis chromosome. Microb Pathog 11: 123-128.

Reed LJ, Muench HA 1938. A simple method of estimating fifty per cent endpoints. Am J Hyg 27: 493-497.

Sodeinde AO, Goguen JD 1988. Genetic analysis of the 9,5kilobase virulence plasmid of Yersinia pestis. Infect Immun 56: $2743-2748$.

Sodeinde AO, Goguen JD 1989. Nucleotide sequence of the plasminogen activator gene of Yersinia pestis: relationship to omp T of Escherichia coli and gene $E$ of Salmonella typhimurium. Infect Immun 57: 1517-1523.

Surgalla MJ, Beesley ED, Albizo JM 1970. Pratical applications of new laboratory methods for plague investigations. Bull WHO 42: 993-997.

Une T, Brubaker RR 1984. In vivo comparison of avirulent Vwa- and Pgm- or $\mathrm{Pst}^{\mathrm{r}}$ phenotypes of yersiniae. Infect Immun 43: 895-900.

Williams JE, Harrison DN, Quan TJ, Mullins JL, Barnes AM, Cavanaugh DC 1978. Atypical plague bacilli isolated from rodents, fleas, and man. Am J Public Health 68: 262-264.

Zsigray RM, Hopper JB, Zukowski K, Chesbro WR 1985. Integration of the Vwa plasmids into the chromosome of Yersinia pestis strains harboring F' plasmids of Escherichia coli. Infect Immun 47: 670-673. 